\title{
Retention in care and adherence to HIV and AIDS treatment in Anambra State Nigeria
}

\author{
Chukwuma David Umeokonkwo ${ }^{1,2^{*}}$ (D), Chima Ariel Onoka ${ }^{3}$, Pearl Adaoha Agu ${ }^{1,4,5}$, Edmund Ndudi Ossai ${ }^{1,4}$, \\ Muhammad Shakir Balogun² and Lawrence Ulu Ogbonnaya ${ }^{1,4,5}$
}

\begin{abstract}
Background: Retaining patients on antiretroviral treatment in care is critical to sustaining the 90:90:90 vision. Nigeria has made some progress in placing HIV-positive patients on treatment. In an effort to increase access to treatment, ART decentralization has been implemented in the country. This is aimed at strengthening lower level health facilities to provide comprehensive antiretroviral treatment. We determined the level of retention and adherence to treatment as well as the associated factors among private and public secondary level hospitals in Anambra State.
\end{abstract}

Method: We conducted a cross-sectional study among patients who had taken antiretroviral treatment for at least one complete year. A structured questionnaire and patient record review were used to extract information on patient adherence to treatment, and retention in care. Adherence to treatment was ascertained by patient self-report of missed pills in the 30 days prior to date of interview. Retention in care was ascertained using the 3-month visit constancy method reviewing the period spanning 12 months prior to the study.

Result: We found a comparable level of retention in care (private 81.1\%; public 80.3\%; $p=0.722$ ). However, treatment adherence was significantly higher amongst participants in the private hospitals compared to those in the public hospitals (private: $95.3 \%$; public: $90.7 \% ; p=0.001$ ). Determinants of good retention in the private hospitals included disclosure of one's HIV status (AOR: 1.94, 95\% Cl: 1.09-3.46), being on first-line regimen (AOR: 3.07, 95\% Cl: 1.27-7.41), whereas being on once-daily regimen (AOR: $0.58,95 \%$ Cl: $0.36-0.92$ ), and being currently married (AOR: $0.5495 \%$ Cl: 0.32-0.91) determined poor retention. In the public hospitals, only disclosure (AOR: 3.12 95\% Cl: 1.81-5.56) determined good retention, whereas, spending less than N1000 on transport (AOR: $0.23095 \% \mathrm{Cl}: 0.07-0.78$ ) and residing in a rural area (AOR: 0.64 95\% Cl: 0.41-0.99) determined poor retention. None of the factors determined adherence.

Conclusion: Retention in care was high and comparable among the different hospital types and HIV disclosure status was an important factor relating to retention in care. The other factors that determined retention were however different at public and private hospitals. The HIV program manager should consider these variations in designing programs to improve patient retention in care and adherence to treatment.

Keywords: HIV, Retention in care, Adherence to treatment, Hospital

\footnotetext{
* Correspondence: chukwumau@gmail.com

'Department of Community Medicine, Federal Teaching Hospital Abakaliki,

Ebonyi State, Nigeria

${ }^{2}$ Nigeria Field Epidemiology and Laboratory Training Programme, Abuja,

Nigeria

Full list of author information is available at the end of the article
}

(c) The Author(s). 2019 Open Access This article is distributed under the terms of the Creative Commons Attribution 4.0 International License (http://creativecommons.org/licenses/by/4.0/), which permits unrestricted use, distribution, and reproduction in any medium, provided you give appropriate credit to the original author(s) and the source, provide a link to the Creative Commons license, and indicate if changes were made. The Creative Commons Public Domain Dedication waiver (http://creativecommons.org/publicdomain/zero/1.0/) applies to the data made available in this article, unless otherwise stated. 


\section{Background}

Provision of antiretroviral treatment to HIV patients has led to longer survival, better quality of life and reduction of HIV transmission. Adherence to treatment and retention in care are critical to achieving these outcome through viral suppression [1-5]. Effective care of people living with HIV/AIDS (PLWHA) requires that patients are provided with satisfactory care, adhere to their treatment regimen and are retained in care. Adherence to therapy is one of the primary determinants of treatment outcome. Some of the major objectives of care and treatment of HIV/AIDS are to reduce morbidity and mortality as well as improve the quality of life of the PLWHA. These objectives among other factors are intricately linked to the achievement of optimal viral suppression which in turn depends on the level of adherence of the patient to treatment. Sustained period of good adherence (not less than 95\%) to therapy is required to achieve adequate viral suppression which in turn is a predictor of good clinical outcome.

Poor adherence on the other hand is not only associated with poorer clinical outcome but also with a risk of developing drug resistance. Poor adherence reduces the optimal clinical outcome and the overall effectiveness of the treatment goal or target. The factors directly affecting patients' level of adherence are diverse. They could be patient-related, treatment-related among others. Complexity of regimen (dosing frequency, pill burden), treatment side effects, poor health literacy, and poor patient-physician relationship have been reported to affect adherence to treatment [2].

Retention in care has variously been defined as "a spectrum of continuum of care packages starting from diagnosis of HIV infection till lifelong services" [6], "being alive and on ART or being transferred out to other health facilities to continue treatment" [7], and "as patients known to be alive and receiving highly active ART at the end of a follow up period" [8]. There is no gold standard in measuring retention in care $[9,10]$. However, for a PLWHA to achieve viral suppression, he or she needs to be retained in care. Systematic reviews of retention in care in sub-Saharan Africa have shown that there was an increase in the level of estimated retention in care after two years on treatment from about $62 \%$ to about $76 \%$ over a period of three years (2007-2010) [8, 11].

Following decentralization of treatment from tertiary hospitals to secondary level hospitals in Nigeria, private hospitals have become intricately involved in the provision of such services due to their peculiar client base. Yet, studies are scarce that compare the treatment outcome in public and private hospitals in order to guide the policy direction for further scale-up activities. To help fill this gap, this study was carried out to compare retention in care, and adherence to treatment among adult HIV patients already on antiretroviral treatment in public and private secondary level hospitals in Anambra State, Nigeria.

\section{Methods}

We conducted a comparative cross-sectional study among adult patients receiving antiretroviral treatment in secondary level hospitals in Anambra State. The hospitals were selected from the list of hospitals providing HIV treatment in the state. The participants were recruited through a multistage probability sampling technique. The details of the study sites, sample size determination and the sampling technique had been discussed fully in an earlier publication [12].

We included 1270 patients who had been on antiretroviral drug treatment for at least one complete year prior to the time of the study, had not been hospitalised or incarcerated for more than one month in the last one year prior to the study and were at least 18 years of age. 'Transferred-in' patients (patients who commenced their antiretroviral treatment in another hospital but who transferred to the index hospital to continue their treatment) were included in the study if they had completed at least one year of treatment in their current hospital before the beginning of the study. Patients whose complete medical records could not be seen (those using temporary case note with limited information) and those who were currently admitted in the hospital were excluded from the study.

\section{Study instrument}

We administered a structured pretested questionnaire on consenting participants. The questionnaire captured information about the participants' socio-demographic and clinical characteristics, as well as the factors affecting retention in HIV care and adherence to antiretroviral treatment. We extracted the patients' adherence record and clinic visits from the patient's case note.

\section{Measurement of variables}

We assessed retention in care using the 3-month visit constancy method $[9,13,14]$. Three months visit constancy method was used because the appointment scheduling team in the study area schedules refill appointments every two months for stable patients and shorter for sick or non-adherent patients. The three months method is more sensitive compared to fourmonth method which is usually used in context where refill visits is scheduled every three months. Patients' visit records for 12 months immediately prior to the study were reviewed. The year was divided into four equal quarters (three months in each quarter). Participants who visited the hospital and received antiretroviral 
refill at least once in each quarter for all the four quarters were classified as having good retention. Otherwise, they were classified as having poor retention.

We assessed adherence to ART using patient selfreport of missed dose in the last one month. We then calculated the proportion of respondents with good adherence to ART based on the expected number of doses the patient had taken in the last 30 days prior to the interview. Participants who took $\geq 95 \%$ of the expected doses of their ART in the preceding 30 days were classified as having good adherence while those that took below 95\% of their ART were classified as having poor adherence. The details of the calculation have earlier been documented [12].

The other explanatory variables assessed were sociodemographic characteristics (age, sex, education, place of residence, marital status, employment status) clinical characteristics (regimen type, regimen dosing frequency), HIV disclosure status and transportation cost.

\section{Data analysis}

The data were entered and analyzed using Epi Info 7.0. We calculated the frequency and proportion of the participants who had good retention and good adherence. The proportion of patients who had good retention and those who had good adherence were compared across public and private hospitals using a Chi-squared test. The relationship between good retention in care and socio-demographic / clinical characteristics was assessed using Chi-squared test. Similarly, the relationship between good adherence to ART and socio-demographic / clinical characteristics was explored using Chi-squared test. We used a $p$ value of 0.1 as a cut-off in selecting variables in the bivariate analysis to be used in the logistic regression model. The variables were examined for collinearity and variance inflation factor less than 3 was set as cut-off. We estimated the adjusted odds ratio, the 95\% confidence interval and a $p$ value was calculated. Significance was then determined from a $p$ value $<0.05$.

\section{Results}

A total of $1,234(97.2 \%)$ participants were on first-line regimen (public: $98.0 \%$; private: $96.4 \%$ ). The participants had spent a comparable period on treatment since commencing of antiretroviral treatment (mean months on treatment for public participants: $53.3 \pm 30.0$; private: $50.1 \pm 27.5$ ). The difference between them was not statistically significant $(p=0.160)$. Participants in public hospitals were more likely to be on 24-hourly medications compared to those in private hospitals (public: $28.2 \%$; private: $21.7 \%$; $p=0.008$ ). The pill burden was however comparable in the two groups of patients $(\mathrm{p}=0.09)$.

More participants in the public hospitals reported missing at least a dose of medication in the preceding four weeks (33.4\%) when compared to private hospital participants $(17.2 \%)$ : the difference being statistically significant $(p<0.001$; Table 1$)$. The major reasons given by the participants for the missed doses were similar in both public and private health facilities. The reasons included forgetfulness (public: 44.8\%, private: $42.2 \%$ ), being away from home (public: $25.9 \%$, private: $36.7 \%$ ), running out of medicines (public: $6.6 \%$, private: $11.0 \%$ ), difficulty taking the medication at the specified time (public: $5.7 \%$, private: $7.3 \%$ ) and drug side effect (public: $3.8 \%$, private: $3.7 \%$ ). Public health facility participants reported lower proportion of good ratings on their ability to take the medication as prescribed (94.8\%) when compared to the participants in the private health facility (96.7\%): the observed difference in proportion being however not statistically significant $(p=0.095)$.

The HIV status disclosure rate by participants was comparable between the public $(89.1 \%)$ and the private $(88.3 \%)$ hospitals $(p=0.657$; Table 2$)$. The disclosures were mainly to spouse, siblings and parents (close family relatives). Participants accessing their care in private health facilities were more likely to disclose to their spouses $(64.5 \%, \mathrm{p}<0.001)$, while the participants accessing their treatment in public health facilities were more likely to disclose to their siblings $(43.8 \%, p<0.001)$ and others $(13.4 \%)$. The other disclosure rates were comparable in the two groups.

The proportion of participants who had good retention in care was comparable in both private $(81.1 \%)$ and public (80.3\%) hospitals $(p=0.722)$. However, greater proportion of participants in the private hospitals (95.3\%) had good adherence to ART compare to those in the public (90.7\%) hospitals $(p=0.001$; Table 3$)$.

Table 4 shows the relationship between participants' socio-demographic characteristics and adequate retention in care in each of the hospital types. The factors with $\mathrm{p}$ value less than 0.1 in the bivariate analysis were modelled for each hospital in a logistic regression (Table 5).

Marital status, regimen type, ART dosing frequency and disclosure status were statistically significant predictors of retention among participants accessing care in private health facilities (Table 5). Participants who had disclosed their status had 1.94 odds of being retained in care compared to those who had not $(p=$ 0.024). Similarly, participants who were on first-line regimen had 3.067 odds of being retained compared to those on second-line regimen $(p=0.013)$.

Table 6 shows the relationship between the sociodemographic and clinical characteristics of the participants, in relation to their adherence to 
Table 1 Participants' reporting missed doses and reasons for missed doses

\begin{tabular}{|c|c|c|c|c|}
\hline Variable & $\begin{array}{l}\text { Public } \\
(\mathrm{N}=635) \text { frequency (\%) }\end{array}$ & $\begin{array}{l}\text { Private } \\
(N=635) \text { frequency }(\%)\end{array}$ & Chi square $\left(x^{2}\right)$ & $p$-value \\
\hline \multicolumn{5}{|c|}{ Missed at least one dose of HIV drug in the past 4 weeks } \\
\hline \multirow[t]{2}{*}{ Yes } & $212(33.4)$ & $109(17.2)$ & 44.23 & $<0.001$ \\
\hline & $n=212$ & $n=109$ & & \\
\hline \multicolumn{5}{|c|}{ Reasons for missed doses by the participants $(n=321)$} \\
\hline Forgetfulness & $95(44.8)$ & $46(42.2)$ & & \\
\hline Away from home & $55(25.9)$ & $40(36.7)$ & & \\
\hline Ran out of drugs & $14(6.6)$ & $12(11.0)$ & & \\
\hline Inconvenient timing & $12(5.7)$ & $8(7.3)$ & & \\
\hline Drug side effect & $8(3.8)$ & $4(3.7)$ & & \\
\hline Too many drugs to take & $7(3.3)$ & $1(0.9)$ & & \\
\hline Confusion on how to take the drugs & $4(1.9)$ & $3(2.8)$ & & \\
\hline Fasting & $4(1.9)$ & $0(0)$ & & \\
\hline Lack of privacy & $4(1.9)$ & $0(0)$ & & \\
\hline Others & $7(3.3)$ & $8(7.3)$ & & \\
\hline \multicolumn{5}{|c|}{ Participants rating of their ability to take medication as prescribed } \\
\hline Good $^{b}$ & $602(94.8)$ & $614(96.7)$ & 2.79 & 0.095 \\
\hline Poor $^{a}$ & $33(5.2)$ & $21(3.3)$ & & \\
\hline
\end{tabular}

ancluded The Ratings Fair, Poor, Very Poor

b Included the ratings good, very good, excellent

antiretroviral treatment. The factors with $p$ value $<$ 0.1 in the bivariate analysis were modelled in logistic regression (Table 7).

None of the factors modelled significantly predicted patient adherence to treatment among participants accessing care in public health facilities. However, among the private hospital participants, experience of stock-out of antiretroviral drugs was a significant negative predictor of adherence to treatment. Those that had experienced stock-outs had 0.206 odds of being adherent to their treatment compared to those who had not $(p=0.004)$.

Table 2 Participants' disclosure of HIV status

\begin{tabular}{|c|c|c|c|c|c|}
\hline Variable & $\begin{array}{l}\text { Public } \\
(\mathrm{N}=635) \text { frequency } \\
(\%)\end{array}$ & $\begin{array}{l}\text { Private } \\
(\mathrm{N}=635) \text { frequency } \\
(\%)\end{array}$ & $\begin{array}{l}\text { Total } \\
(N=1270) \text { frequency } \\
(\%)\end{array}$ & $\begin{array}{l}\text { Chi square } \\
\left(x^{2}\right)\end{array}$ & $\begin{array}{l}p- \\
\text { value }\end{array}$ \\
\hline \multicolumn{6}{|c|}{ Participants who have disclosed their HIV status to someone } \\
\hline Yes & $566(89.1)$ & $561(88.3)$ & $1127(88.7)$ & 0.18 & 0.657 \\
\hline No & $69(10.9)$ & $74(11.7)$ & $143(11.3)$ & & \\
\hline $\begin{array}{l}\text { Who the Participants disclosed their HIV status } \\
\text { to }\end{array}$ & $N=566$ & $N=561$ & $N=1127$ & & \\
\hline Spouse & $301(53.2)$ & $362(64.5)$ & $663(58.8)$ & 11.74 & $\begin{array}{l}< \\
0.001\end{array}$ \\
\hline Siblings & $248(43.8)$ & $170(30.3)$ & $418(37.1)$ & 21.70 & $\begin{array}{l}< \\
0.001\end{array}$ \\
\hline Parents & $107(18.9)$ & $104(18.5)$ & $211(18.7)$ & 0.05 & 0.821 \\
\hline Friends & $31(5.5)$ & $28(5.0)$ & $59(5.2)$ & 0.16 & 0.689 \\
\hline In law & $7(1.2)$ & $8(1.4)$ & $15(1.3)$ & 0.07 & 0.795 \\
\hline Colleague at work & $5(0.9)$ & $6(1.1)$ & $11(1.0)$ & 0.09 & 0.762 \\
\hline Neighbour & $7(87.5)$ & $1(12.5)$ & $8(0.6)$ & 3.15 & 0.076 \\
\hline Others $^{\mathrm{b}}$ & $76(13.4)$ & $45(8.0)$ & $121(10.7)$ & 8.78 & 0.003 \\
\hline
\end{tabular}

aultiple response allowed

${ }^{\mathrm{b}}$ Children 
Table 3 Retention in care and adherence to treatment among HIV patients receiving treatment from secondary level hospitals in Anambra State, Nigeria

\begin{tabular}{llll}
\hline Variable & $\begin{array}{l}\text { Public }(n=635) \\
\text { Frequency (\%) }\end{array}$ & $\begin{array}{l}\text { Private }(n=635) \\
\text { Frequency (\%) }\end{array}$ & Chi square $\left(x^{2}\right)$ \\
\hline $\begin{array}{l}\text { Retention in care } \\
\text { Adequate retention } \\
\text { Inadequate retention }\end{array}$ & $510(80.3)$ & $515(81.1)$ & 0.126 \\
Adherence to treatment & $125(19.7)$ & $120(18.9)$ & 10.16 \\
Adequate adherence & & $605(95.3)$ & 0.722 \\
Inadequate adherence & $576(90.7)$ & $30(4.7)$ & 0.001 \\
\hline
\end{tabular}

\section{Discussion}

The proportion of patients retained in care in both facility types was high. The high rate was commendable bearing in mind that it was a composite measure of retention for patients who had completed at least one year on antiretroviral therapy. The retention rates achieved among the participants were comparable with those found in other studies carried out in Nigeria, other parts of Africa and elsewhere [15-20]. Retention in care has been argued as a marker of quality of care and an important requirement for patients to achieve viral suppression and other important beneficial outcome in HIV treatment. A lower rate of retention was previously reported in a public tertiary hospital in the region [17]. It has been argued that, congestion in the tertiary hospitals and occasional excessive demand on their scarce resources, makes it difficult for the tertiary hospitals to retain most of their patients.

The high rate of retention has a great significance for the decentralization efforts of the government in making ART services more accessible to the populace. There have been fears that lower level health facilities do not have the capacity to provide comprehensive treatment for people living with HIV. Despite these fears, there was a need to decentralize care to more centres since the public tertiary hospitals were few and far apart. This made the provision of these services difficult as patients had to travel long distances and spend more hours trying to access care, with the consequent effect on quality of services and retention. The high rates observed in these types of hospital support the fact that secondary health facilities could effectively provide these treatments. The comparability of the rates in both facility types signifies that private health facilities had the capacity to actively engage and retain a substantial number of their clients on lifelong therapy in care. These findings support the addition of private facilities that meet the criteria to provide comprehensive HIV care and treatment. This would help increase geographical access to treatment for a greater number of patients and reduce their transportation costs.
This study revealed a high level of patient adherence to treatment in both public and private health facilities. It is noteworthy that all the health facilities that participated in the study had a functional adherence unit. The units were involved in treatment preparation of patients before they were commenced on ART and provided ongoing adherence counselling and support to all those on treatment. The high levels of adherence observed in this study was comparable to the other studies in Nigeria and Africa [21-25]. The proportion of patients with good adherence to treatment was however higher than that reported in two other studies in Togo and Nepal which reported adherence levels of $78.4 \%$ [26] and $85 \%$ respectively [27]. In the study that reported an adherence level of $78.4 \%$, a composite measure combining the patient self-report, pill count and appointment adherence was used to calculate the global composite adherence as against the patient selfreport used in our study and that could have resulted in the lower value. Similarly, the study that reported $85 \%$ level of adherence used total adherence (that is $100 \%$ adherence with no missed dose during the period of observation) instead of the 95\% standard level which could have accounted for the recording of a lower adherence level.

The difference in adherence between the two hospitals, though small, might become clinically important especially when the numbers are large. The most feared consequence of poor adherence to ART is the development of resistance to ART. The resistance developed is transmissible to other individuals who become resistance even before being exposed to ART. The implication of this in an environment with HIV epidemic needs immediate intervention to address.

The proportion of participants who had missed at least a dose of their medication was significantly higher in public health facilities. The higher rate of missed doses among participants in public health facilities, which was twice as high as observed in the private health facilities, is a cause for concern. The high proportion of participants who had missed at least one dose of their ART in the preceding four weeks could have explained the difference observed in the adherence rate in public and 
Table 4 Relationship between socio-demographic/clinical characteristics and retention in care in public and private hospitals in Anambra State, Nigeria

\begin{tabular}{|c|c|c|c|c|c|c|}
\hline \multirow[t]{2}{*}{ Variable } & \multicolumn{3}{|l|}{ Public hospital } & \multicolumn{3}{|l|}{ Private hospital } \\
\hline & Good retention (\%) & COR $(95 \% \mathrm{Cl})$ & $p$-value & Good retention (\%) & COR $(95 \% \mathrm{Cl})$ & $p$-value \\
\hline \multicolumn{7}{|l|}{ Age } \\
\hline Less than 35 yrs & $135(75.7)$ & $0.7(0.44-1.00)$ & 0.048 & $164(82.4)$ & $1.13(0.73-1.75)$ & 0.569 \\
\hline $35 \mathrm{yrs}$. and older & $357(82.5)$ & & & $351(80.5)$ & & \\
\hline \multicolumn{7}{|l|}{ Gender } \\
\hline Male & $140(82.4)$ & $0.8(0.53-1.31)$ & 0.435 & 149 (78.8) & $1.2(0.80-1.88)$ & 0.342 \\
\hline Female & $370(79.6)$ & & & $366(82.1)$ & & \\
\hline \multicolumn{7}{|l|}{ Marital Status } \\
\hline Currently Married & $300(80.9)$ & $1.1(0.73-1.61)$ & 0.681 & $381(79.4)$ & $0.6(0.36-1.00)$ & 0.050 \\
\hline Not Currently married ${ }^{a}$ & $210(79.6)$ & & & $134(134)$ & & \\
\hline \multicolumn{7}{|l|}{ Employment status } \\
\hline Employed & $451(82.0)$ & $2.0(1.21-3.34)$ & 0.007 & $465(81.3)$ & $1.1(0.59-2.15)$ & 0.711 \\
\hline Unemployed & $59(69.4)$ & & & $50(79.4)$ & & \\
\hline \multicolumn{7}{|l|}{ Place of residence } \\
\hline Rural & $154(76.2)$ & $0.7(0.46-1.04)$ & 0.078 & $165(84.6)$ & $1.4(0.90-2.22)$ & 0.132 \\
\hline Urban & $356(82.2)$ & & & 350 (79.6) & & \\
\hline \multicolumn{7}{|l|}{ Education } \\
\hline Primary education or less & $224(84.5)$ & $1.6(1.06-2.42)$ & 0.024 & $107(74.8)$ & $0.6(0.39-0.95)$ & 0.029 \\
\hline Secondary education and more & $286(77.3)$ & & & $408(82.9)$ & & \\
\hline \multicolumn{7}{|l|}{ Dosing frequency } \\
\hline 12 hrly & $371(81.4)$ & $0.8(0.52-1.22)$ & 0.291 & $412(82.9)$ & $0.6(0.39-0.95)$ & 0.028 \\
\hline 24 hrly & $139(77.7)$ & & & $103(74.6)$ & & \\
\hline \multicolumn{7}{|l|}{ Regimen type } \\
\hline First line & $502(80.7)$ & $2.6(0.84-8.13)$ & 0.085 & $501(81.9)$ & $2.9(1.22-6.87)$ & 0.012 \\
\hline Second line & $8(61.5)$ & & & $14(60.9)$ & & \\
\hline \multicolumn{7}{|l|}{ Experienced stock out } \\
\hline Yes & $256(85.1)$ & $1.8(1.2-2.68)$ & 0.004 & $20(74.1)$ & $0.7(0.27-1.58)$ & 0.340 \\
\hline No & $254(76.1)$ & & & $495(81.4)$ & & \\
\hline \multicolumn{7}{|l|}{ Disclosure status } \\
\hline Yes & $471(83.2)$ & $3.8(2.26-6.44)$ & $<0.001$ & $461(82.2)$ & $1.7(0.98-2.98)$ & 0.057 \\
\hline No & $39(56.5)$ & & & $54(73.0)$ & & \\
\hline \multicolumn{7}{|l|}{ Transportation cost } \\
\hline Less than 1000 & $470(79.4)$ & $0.3(0.09-0.95)$ & 0.030 & $455(80.7)$ & $0.8(0.39-1.50)$ & 0.437 \\
\hline More than 1000 & $40(93.0)$ & & & $60(84.5)$ & & \\
\hline
\end{tabular}

${ }^{\mathrm{a}}=$ Not currently married included Single (never married), Separated, Divorced and Widowed COR $=$ Crude odds ratio

private health facility. This calls for an effort to intervene in the factors militating against the participants' ability to adhere completely to their medications. The finding is in keeping with that reported earlier in Anambra [22] but lower than the rate reported in Uganda [21]. The higher proportion of participants who had missed at least one dose of their medication observed in the Ugandan study was probably because of the longer duration of period under review ("ever fail to take ones ARV drugs") as against one-month review period used in this study.

The main reasons adduced for the missed doses were forgetfulness, being away from home, running out of drugs, difficulty taking drugs at specified time, and drug side effects. The reasons observed in this study was in keeping with those observed in similar studies done in Nigeria and Africa [21-24, 28, 29]. Forgetfulness and being away from home (or drug) at the time the medication 
Table 5 Multivariable logistic regression of factors associated with adequate patients' retention in public and private hospitals

\begin{tabular}{|c|c|c|c|c|c|c|}
\hline \multirow[t]{2}{*}{ Independent variable } & \multicolumn{3}{|l|}{ Public hospital } & \multicolumn{3}{|l|}{ Private hospital } \\
\hline & Adjusted Odds Ratio & $(95 \% \mathrm{Cl})$ & $p$-value & Adjusted Odds Ratio & $(95 \% \mathrm{Cl})$ & $p$-value \\
\hline \multicolumn{7}{|l|}{ Age } \\
\hline Less than 35 & 0.9 & $0.56-1.37$ & 0.566 & & & \\
\hline 35 years and more & 1 & & & & & \\
\hline \multicolumn{7}{|l|}{ Education } \\
\hline Primary education or less & 1.4 & $0.90-2.19$ & 0.135 & 0.7 & $0.42-1.05$ & 0.077 \\
\hline Secondary education or more & 1 & & & 1 & & \\
\hline \multicolumn{7}{|l|}{ Marital status } \\
\hline Currently married & & & & 0.5 & $0.32-0.91$ & 0.021 \\
\hline Not currently married & & & & 1 & & \\
\hline \multicolumn{7}{|l|}{ Employment status } \\
\hline Employed & 1.6 & $0.90-2.74$ & 0.112 & & & \\
\hline Unemployed & 1 & & & & & \\
\hline \multicolumn{7}{|l|}{ Place of residence } \\
\hline Rural & 0.6 & $0.41-0.99$ & 0.045 & & & \\
\hline Urban & 1 & & & & & \\
\hline \multicolumn{7}{|l|}{ Dosing frequency } \\
\hline 24 hourly & & & & 0.58 & $0.36-0.92$ & 0.021 \\
\hline 12 hourly & & & & 1 & & \\
\hline \multicolumn{7}{|l|}{ Regimen type } \\
\hline First line & 2.5 & $0.79-8.18$ & 0.120 & 3.1 & $1.27-7.41$ & 0.013 \\
\hline Second line & 1 & & & 1 & & \\
\hline \multicolumn{7}{|l|}{ Experienced stock out } \\
\hline Yes & 1.7 & $1.09-2.54$ & 0.018 & & & \\
\hline No & 1 & & & & & \\
\hline \multicolumn{7}{|l|}{ Disclosure status } \\
\hline Yes & 3.2 & $1.81-5.56$ & $<0.001$ & 1.9 & $1.09-3.46$ & 0.024 \\
\hline No & 1 & & & 1 & & \\
\hline \multicolumn{7}{|l|}{ Transportation Cost (N) } \\
\hline 1000 and below & 0.2 & $0.07-0.78$ & 0.019 & & & \\
\hline More than 1000 & 1 & & & & & \\
\hline
\end{tabular}

should be taken were the commonest reasons for missing medication. Efforts targeted at reminding the patients at the time that they should take their medication and having their drugs with them while away from home could help improve the level of adherence among the participants. The use of alarms, pillboxes, text messages and calendars have been reported to assist patients improve their adherence [30-32]. Efforts aimed at personalizing adherence counselling and tying the time of medication intake to patient routines could also help improve adherence levels.

Participants in public health facilities also reported higher frequencies of stock-out (inability to receive their antiretroviral drugs on scheduled visit date due to nonavailability at the health facility) in the twelve months preceding the study. This may have contributed to the poor adherence level, as running out of drugs were among the factors given by patients for missing their medications. Patients that were not able to get their drugs as scheduled were more at risk of running out of their medication. The public health facilities need to devise better strategies of managing their drug supply chain to minimize incidences of antiretroviral drug stock out in the facilities.

The level of adherence was significantly higher in private compared to the public health facilities. This could have been due to multi-dimensional nature of the adherence to treatment concept which goes beyond the health worker patient interaction to other patient-centred and 
Table 6 Relationship between socio-demographic/clinical characteristics and patients' adherence to treatment in public and private hospital

\begin{tabular}{|c|c|c|c|c|c|c|}
\hline \multirow[t]{2}{*}{ Variable } & \multicolumn{3}{|l|}{ Public Hospital } & \multicolumn{3}{|l|}{ Private Hospital } \\
\hline & Good Adherence (\%) & COR $(95 \% \mathrm{Cl})$ & $p$-value & Good Adherence (\%) & $\operatorname{COR}(95 \% \mathrm{Cl})$ & $p$-value \\
\hline \multicolumn{7}{|l|}{ Age } \\
\hline$<35$ yrs & $175(86.6)$ & $0.5(0.30-0.89)$ & 0.016 & $192(96.5)$ & $1.5(0.64-3.62)$ & 0.333 \\
\hline$\geq 35$ yrs. & $401(92.6)$ & & & $413(94.7)$ & & \\
\hline \multicolumn{7}{|l|}{ Gender } \\
\hline Male & $159(93.5)$ & $1.7(0.84-3.28)$ & 0.139 & $426(95.5)$ & $1.2(0.55-2.59)$ & 0.661 \\
\hline Female & $417(89.7)$ & & & $179(94.7)$ & & \\
\hline \multicolumn{7}{|l|}{ Marital Status } \\
\hline Currently Married & $342(92.2)$ & $1.5(0.88-2.59)$ & 0.129 & $457(95.2)$ & $0.9(0.40-2.23)$ & 0.889 \\
\hline Not Currently married & $234(88.6)$ & & & $148(95.5)$ & & \\
\hline \multicolumn{7}{|l|}{ Employment Status } \\
\hline Employed & $503(91.5)$ & $1.8(0.89-3.47)$ & 0.099 & $546(95.5)$ & $1.4(0.48-4.22)$ & 0.522 \\
\hline Unemployed & $73(85.9)$ & & & $59(93.7)$ & & \\
\hline \multicolumn{7}{|l|}{ Place of Residence } \\
\hline Rural & $182(90.1)$ & $0.9(0.51-1.59)$ & 0.718 & $188(96.4)$ & $1.5(0.62-3.51)$ & 0.370 \\
\hline Urban & $394(91.0)$ & & & 417 (94.8) & & \\
\hline \multicolumn{7}{|l|}{ Education } \\
\hline$\leq$ Primary Education & 248 (93.6) & $1.9(1.04-3.36)$ & 0.035 & $136(95.1)$ & $1.0(0.40-2.27)$ & 0.913 \\
\hline$\geq$ Secondary Education & $328(88.7)$ & & & $469(95.3)$ & & \\
\hline \multicolumn{7}{|l|}{ Dosing Frequency } \\
\hline 12hrly & 417 (91.5) & $0.7(0.42-1.31)$ & 0.306 & $473(95.2)$ & $1.1(0.44-2.79)$ & 0.814 \\
\hline 24hrly & $159(88.8)$ & & & $132(95.7)$ & & \\
\hline \multicolumn{7}{|l|}{ Regimen Type } \\
\hline First line & $565(90.8)$ & $1.8(0.39-8.33)$ & 0.444 & 585 (95.6) & $3.3(0.91-11.61)$ & 0.055 \\
\hline Second line & $11(84.6)$ & & & $20(87.0)$ & & \\
\hline \multicolumn{7}{|l|}{ Experienced Stock out } \\
\hline Yes & $270(89.7)$ & $0.8(0.47-1.36)$ & 0.406 & $22(81.5)$ & $0.2(0.06-0.54)$ & $<0.001$ \\
\hline No & 306 (91.6) & & & $583(95.9)$ & & \\
\hline \multicolumn{7}{|l|}{ Disclosure Status } \\
\hline Yes & $514(90.8)$ & $1.1(0.49-2.56)$ & 0.796 & $533(95.0)$ & $0.5(0.13-2.27)$ & 0.383 \\
\hline No & $62(89.9)$ & & & $72(97.3)$ & & \\
\hline
\end{tabular}

$C O R=$ Crude odds ratio

treatment-centred factors. It could probably be due to more stringent and personal measures taken by the adherence units of the private hospitals studied. One of the practices observed was more frequent and personalized follow-up calls and visits especially when patients missed their appointments. They were done usually within a day or two after missing a scheduled appointment. This finding highlights the need, in the public hospitals, for a more personalized follow-up of patients on treatment especially when they miss their scheduled appointments soon after the appointments. Such strategies have similarly been reported to promote retention in private facilities in the study area [17]. The follow up calls were done usually within a day or two after missing a scheduled appointment. This finding further justifies the need for more personalized and timely follow up of patients on treatment especially soon after they miss their scheduled appointments.

The variation in the predictors between public and private health facilities could be due to the differences observed in the socio-demographic characteristics. The effect of disclosure of one's HIV status to retention in care could be due to the social support it provides. It has been reported that non-disclosure of HIV status was associated with poor retention in care [33]. Efforts at encouraging patients to disclose their status to close family relatives 
Table 7 Multivariable logistic regression of factors associated with patients' adherence to treatment in public and private hospitals in Anambra State

\begin{tabular}{|c|c|c|c|c|c|c|}
\hline \multirow{2}{*}{$\begin{array}{l}\text { Independent variables } \\
n=635\end{array}$} & \multicolumn{3}{|l|}{ Public hospital } & \multicolumn{3}{|l|}{ Private hospital } \\
\hline & Adjusted Odds Ratio & $(95 \% \mathrm{Cl})$ & $p$-value & Adjusted Odds Ratio & $(95 \% \mathrm{Cl})$ & $p$-value \\
\hline \multicolumn{7}{|l|}{ Age } \\
\hline$<35$ years & 0.6 & $0.34-1.05$ & 0.074 & & & \\
\hline$\geq 35$ years & 1 & & & & & \\
\hline \multicolumn{7}{|l|}{ Experienced Stock out } \\
\hline Yes & & & & 0.2 & $0.07-0.60$ & 0.004 \\
\hline No & & & & 1 & & \\
\hline \multicolumn{7}{|l|}{ Regimen Type } \\
\hline First line & & & & 2.7 & $0.71-10.00$ & 0.145 \\
\hline Second line & & & & 1 & & \\
\hline \multicolumn{7}{|l|}{ Education } \\
\hline$\leq$ Primary education & 1.6 & $0.89-2.99$ & 0.110 & & & \\
\hline$\geq$ Secondary education & 1 & & & & & \\
\hline \multicolumn{7}{|l|}{ Employment } \\
\hline Employed & 1.5 & $0.73-2.94$ & 0.288 & & & \\
\hline Unemployed & 1 & & & & & \\
\hline
\end{tabular}

and friends which was observed as a common practice among the study population, should be encouraged. Other benefits associated with disclosure of HIV status have been reported [34].

Among the participants in the public hospitals, none of the factors modelled significantly predicted patient's adherence to treatment. However, among participants in the private hospitals, experience of stock-out was a negative predictor of adherence to treatment among the private health facilities' participants. A multicentre study involving five tertiary public health facilities in Nigeria concluded that HIV disclosure status to either spouse or family member and Tenofovir-containing first-line regimens were significant positive predictor of good adherence [35]. Other studies have also reported different predictors of adherence to treatment in different populations and settings. Disclosure of HIV status [36, 37], education [36], duration on ART treatment [37] and alcohol use [36] have all been reported as predictors of adherence to treatment. These were not however elicited in this study.

Our study assessed the retention in care among those who have already spent at least one year on antiretroviral treatment. This may limit the generalization of our study. We were not able to assess retention among patients within the first year of beginning ART neither did we assess long term longitudinal retention. Combining all the patients who have been on ART for at least one year might have masked the variations that could have existed over the different periods on treatment. There is need for qualitative study to understand the underlying reasons for the differences observed in the two hospital types.

\section{Conclusion}

Our study further strengthens the findings that support decentralization of HIV services to lower secondary level hospitals. It also reveals that secondary level hospitals were able to retain HIV patients while recording high level of adherence to antiretroviral among the patients. The factors that determine who is retained were however different in public and private hospitals. The HIV program manager are therefore encouraged to consider these variations in designing programs aimed at improving patient retention and adherence to treatment.

\section{Abbreviation}

AIDS: Acquired Immunodeficiency Syndrome; AOR: Adjusted odds ratio; ART: Antiretroviral treatment; ARV: Antiretroviral; Cl: Confidence interval; HIV: Human immunodeficiency virus; PLWH: People living with HIV/AIDS

\section{Acknowledgements}

We acknowledge the Management team of the participating hospitals for their support during the data collection phase of the study.

\section{Author's contributions}

CDU: Conceptualized the study, designed it, acquired the data, conducted statistical analysis and interpretation, drafted the initial manuscript and made reviews on the final manuscript. CAO: Supervised the study, interpretation of result, made substantial review to the final manuscript. PAA: made substantial review to the final manuscript. ENO: made substantial review to the final manuscript. MSB: made substantial review to the final manuscript. LO: made substantial review to the final manuscript. All authors read and approved the final version of the manuscript.

Funding

The authors did not receive any funding for this work. 


\section{Availability of data and materials}

The data generated in the course of the study is freely available online at (https://doi.org/10.3886/E103460V1).

\section{Ethics approval and consent to participate}

The ethical approval for the study was obtained from the Research and Ethics Committee of Federal Teaching Hospital Abakaliki, Ebonyi State Nigeria with the reference number FETHA/RECNNol1/2015/232 dated 23rd February 2015. We also obtained written informed consent from the participants.

\section{Consent for publication}

Not applicable.

\section{Competing interests}

The authors declare that they have no competing interests.

\section{Author details}

'Department of Community Medicine, Federal Teaching Hospital Abakaliki, Ebonyi State, Nigeria. ${ }^{2}$ Nigeria Field Epidemiology and Laboratory Training Programme, Abuja, Nigeria. ${ }^{3}$ Department of Community Medicine, University of Nigeria Teaching Hospital Ituku Ozalla, Enugu State, Nigeria. ${ }^{4}$ Department of Community Medicine, College of Health Sciences, Ebonyi State University Abakaliki, Ebonyi State, Nigeria. ${ }^{5}$ African Institute for Health Policy and Health Systems, Ebonyi State University Abakaliki Ebonyi State, Ebonyi State, Nigeria.

Received: 14 March 2019 Accepted: 16 July 2019

Published online: 22 July 2019

\section{References}

1. Viswanathan S, Detels R, Mehta SH, Macatangay BJC, Kirk GD, Jacobson LP. Level of adherence and HIV RNA suppression in the current era of highly active antiretroviral therapy (HAART). AIDS Behav. 2015;19(4):601-11.

2. Schaecher KL. The importance of treatment adherence in HIV. Am J Manag Care. 2013;19(12 Suppl):s231-7.

3. Gardner EM, McLees MP, Steiner JF, Del Rio C, Burman WJ. The spectrum of engagement in HIV care and its relevance to test-and-treat strategies for prevention of HIV infection. Clin Infect Dis. 2011;52(6):793-800.

4. Giordano TP, Gifford AL, White AC, Suarez-Almazor ME, Rabeneck L, Hartman C, et al. Retention in care: a challenge to survival with HIV infection. Clin Infect Dis. 2007:44(11):1493-9.

5. Park WB, Choe PG, Kim S-H, Jo JH, Bang JH, Kim HB, et al. One-year adherence to clinic visits after highly active antiretroviral therapy: a predictor of clinical progress in HIV patients. J Intern Med Blackwell Publishing Ltd. 2007;261(3):268-75.

6. World Health Organisation. Retention in HIV Programmes: defining the challenges and identifying solutions. World Health Organisation Geneva. 2011.

7. Massaquoi M, Zachariah R, Manzi M, Pasulani O, Misindi D, Mwagomba B, et al. Patient retention and attrition on antiretroviral treatment at district level in rural Malawi. Trans R Soc Trop Med Hyg. 2009;103(6):594-600.

8. Rosen S, Fox MP, Gill CJ. Patient retention in antiretroviral therapy programs in sub-Saharan Africa: a systematic review. PLoS Med. 2007;4(10):e298.

9. Mugavero MJ, Westfall AO, Zinski A, Davila J, Drainoni M, Gardner LI, et al. Measuring retention in HIV care: the elusive gold standard. J Acquir Immune Defic Syndr. 2012;61(5):574-80.

10. Mugavero MJ, Davila JA, Nevin CR, Giordano TP. From access to engagement: measuring retention in outpatient HIV clinical care. AIDS Patient Care STDs. 2010;24(10):607-13.

11. Lessells RJ, Mutevedzi PC, Iwuji CC, Newell M-L. Reduction in early mortality on antiretroviral therapy for adults in rural South Africa since change in CD4+ cell count eligibility criteria. J Acquir Immune Defic Syndr. 2014;65(1):e17-24.

12. Umeokonkwo CD, Aniebue PN, Onoka CA, Agu AP, Sufiyan MB, Ogbonnaya L. Patients' satisfaction with HIV and AIDS care in Anambra state, Nigeria. PLoS One. 2018;13(10):e0206499.

13. Mugavero MJ, Amico KR, Horn T, Thompson MA. The state of engagement in HIV Care in the United States : from Cascade to continuum to control. Clin Infect Dis. 2013;57(8):1164-71.

14. Yehia BR, Fleishman JA, Metlay JP, Korthuis PT, Agwu AL, Berry SA, et al. Comparing different measures of retention in outpatient HIV care. AIDS. 2012;26(9):1131-9.
15. Mutasa-Apollo T, Shiraishi RW, Takarinda KC, Dzangare J, Mugurungi O, Murungu J, et al. Patient retention, clinical outcomes and attritionassociated factors of HIV-infected patients enrolled in Zimbabwe's National Antiretroviral Therapy Programme, 2007-2010. PLoS One. 2014;9:e86305.

16. Ekouevi DK, Balestre E, Ba-Gomis F-O, Eholie SP, Maiga M, Amani-Bosse C, et al. Low retention of HIV-infected patients on antiretroviral therapy in 11 clinical centres in West Africa. Trop Med Int Heal. 2010;15(Suppl 1):34-42.

17. Onoka CA, Uzochukwu BS, Onwujekwe OE, Chukwuka C, llozumba J, Onyedum C, et al. Retention and loss to follow-up in antiretroviral treatment programmes in Southeast Nigeria. Pathog Glob Health. 2012; 106(1):46-54

18. Fox MP, Rosen S. Patient retention in antiretroviral therapy programs up to three years on treatment in sub-Saharan Africa, 2007-2009: systematic review. Tropical Med Int Health. 2010;15(SUPPL:1):1-15.

19. Rebeiro PF, Gange SJ, Horberg MA, Abraham AG, Napravnik S, Samji H, et al. Geographic variations in retention in care among HIV-infected adults in the United States. PLoS One. 2016;11(1):e0146119.

20. Fox MP, Rosen S. Retention of adult patients on antiretroviral therapy in low- and middle-income countries: systematic review and meta-analysis 2008-2013. J Acquir Immune Defic Syndr. 2015;69(1):98-108.

21. Senkomago V, Guwatudde D, Breda M, Khoshnood K. Barriers to antiretroviral adherence in HIV-positive patients receiving free medication in Kayunga, Uganda. AIDS Care. 2011;23(10):1246-53.

22. Onyeonoro UU, Ebenebe UE, Ibe CC, Nwamoh UN, Ukaegbu AUEO. Adherence to antiretroviral therapy among people living with human immunodeficiency virus/acquired immunodeficiency syndrome in a tertiary health facility in south eastern Nigeria. J HIV Hum Reprod. 2013;1(2):58-63.

23. Amberbir A, Woldemichael K, Getachew S, Girma B, Deribe K. Predictors of adherence to antiretroviral therapy among HIV-infected persons: a prospective study in Southwest Ethiopia. BMC Public Health. 2008;8(1):265.

24. Vyankandondera J, Mitchell K, Asiimwe-Kateera B, Boer K, Mutwa P, Balinda $J$ - , et al. Antiretroviral therapy drug adherence in Rwanda: perspectives from patients and healthcare workers using a mixed-methods approach. AIDS Care. 2013:25(12):1504-12.

25. Nachega JB, Stein DM, Lehman DA, Hlatshwayo D, Mothopeng R, Chaisson

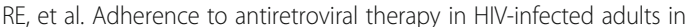
Soweto, South Africa. AIDS Res Hum Retrovir. 2004;20(10):1053-6.

26. Yaya I, Landoh DE, Saka B, Patchali PM, Wasswa P, Aboubakari A-S, et al. Predictors of adherence to antiretroviral therapy among people living with HIV and AIDS at the regional hospital of Sokodé, Togo. BMC Public Health. 2014;14(1):1308

27. Wasti SP, Simkhada P, Randall J, Freeman JV, van Teijlingen E. Factors influencing adherence to antiretroviral treatment in Nepal: a mixedmethods study. PLoS One. 2012;7(5):e35547.

28. Miyasu Z, Kabir M, Abubakar IS, Babashani M, Zubair ZA. Compliance to antiretroviral therapy among AIDS patients in Aminu Kano teaching hospital, Kano. Nigeria Niger J Med. 2005;14(3):290-4.

29. Uzochukwu BSC, Onwujekwe OE, Onoka AC, Okoli C, Uguru NP, Chukwuogo OI. Determinants of non-adherence to subsidized anti-retroviral treatment in Southeast Nigeria. Health Policy Plan. 2009;24(3):189-96.

30. Petersen ML, Wang Y, van der Laan MJ, Guzman D, Riley E, Bangsberg DR. Pillbox organizers are associated with improved adherence to HIV antiretroviral therapy and viral suppression: a marginal structural model analysis. Clin Infect Dis. 2007;45(7):908-15.

31. Holtzman CW, Shea JA, Glanz K, Jacobs LM, Gross R, Hines J, et al. Mapping patient-identified barriers and facilitators to retention in HIV care and antiretroviral therapy adherence to Andersen's behavioral model. AIDS Care. 2015;27(7):817-28.

32. Maduka $\mathrm{O}$, Tobin-West $\mathrm{C}$. Adherence counseling and reminder text messages improve uptake of antiretroviral therapy in a tertiary hospital in Nigeria. Niger J Clin Pract. 2013;16(3):302-8.

33. Elopre L, Hook EW, Westfall AO, Zinski A, Mugavero MJ, Turan J, et al. The role of early HIV status disclosure in retention in HIV care. AIDS Patient Care STDs. 2015;29(12):646-50.

34. Stirratt MJ, Remien RH, Smith A, Copeland OQ, Dolezal C, Krieger D. The role of HIV serostatus disclosure in antiretroviral medication adherence. AIDS Behav. 2006;10(5):483-93.

35. Charurat M, Oyegunle M, Benjamin R, Habib A, Eze E, Ele P, et al. Patient retention and adherence to antiretrovirals in a large antiretroviral therapy program in Nigeria: a longitudinal analysis for risk factors. PLoS One. 2010;5(5):e10584. 
36. Skwara P, Bociąga-Jasik M, Kalinowska-Nowak A, Sobczyk-Krupiarz I, Garlicki A. Adherence to single-tablet versus multiple-tablet regimens in the treatment of HIV infection-a questionnaire-based survey on patients satisfaction. HIV AIDS Rev. 2014;13(3):95-9.

37. Pahari S, Roy S, Mandal A, Kuila S, Panda S. Adherence to anti-retroviral therapy \& factors associated with it: a community based cross-sectional study from West Bengal, India. Indian J Med Res. 2015;142(3):301-10.

\section{Publisher's Note}

Springer Nature remains neutral with regard to jurisdictional claims in published maps and institutional affiliations.

Ready to submit your research? Choose BMC and benefit from:

- fast, convenient online submission

- thorough peer review by experienced researchers in your field

- rapid publication on acceptance

- support for research data, including large and complex data types

- gold Open Access which fosters wider collaboration and increased citations

- maximum visibility for your research: over $100 \mathrm{M}$ website views per year

At $\mathrm{BMC}$, research is always in progress.

Learn more biomedcentral.com/submissions 